\title{
From centralisation to local policies: design reform dynamics in Belgium and the creation of Antwerp's Higher Institute (1830-1914)
}

From the country's unity until World War I, the Belgian Government launched several initiatives resulting in the longed-for project of creating national unity and consciousness through artistic instruction. The aim was to heal the rift between fine arts and applied arts, directing the latter to industrial production. Antwerp's Academy, thanks to its strategic role as one of Belgium's most important educational institutions, was consequently involved in this project, with its goal of bringing "good taste" to all social classes - and aiding in the economic, politic and cultural progression of the country. design education, Belgian design reform, design policies

\section{Introduction}

Design reform in Belgium in the period between independence and World War I was the result of an interaction between public and private initiatives. The Belgian case-study is particularly relevant to illustrate these dynamics on its liberal political culture. A culture which at many levels deeply embraced the problems of education and their social impact, as both private entrepreneurs and public power used arts and culture to support their political and industrial ambitions.

\section{Art, education and national consciousness}

Nineteenth-century Belgium was a state with increasing industrialisation and a solid economy. Its large industrial production, compared to those of neighbouring countries, especially France and England, suffered from a lack of artistic quality which limited Belgian competitiveness on international markets. To remedy this situation, in the aftermath of London's Great Exhibition the Belgian government launched a reform of art education to instil "good taste" in the masses. However, it lacked impetus and proceeded slowly, remaining entangled in classicism trammels'. Nevertheless, at the same time, a number of private initiatives aimed at promoting design reforms, strengthened the government's awareness to engage with a theme: the relationship between art and industry - something which remained central for the economy of the young nation-state. The growing attention to the art-industry debate and the importance of its repercussions, is revealed through

\footnotetext{
'Prina, D. N. (2010), 'Design in Belgium before Art Nouveau: art, industry, and the reform of artistic education in the second half of the nineteenth century' Journal of Design History, vol. 23(4), pp. 329-350. ${ }^{2}$ Exposition des Académies et des écoles de dessin et Congrès de l'enseignement des arts du dessin (1869) Bruxelles: Lelong.
} 
theme 5

society

Figure 1.

The Jubilee Exhibition building (1880). strand 1

design policies

several significant events: from the feeble attempts at launching educational reforms to the organisation, in 1868, of a major conference on the teaching of drawing (the first in Europe) $)^{2}$, which led to the creation of measures such as the establishment of new study programs for art academies - approved in $1874^{3}$. The crucial role of applied and industrial arts was also reflected in the numerous Belgian exhibitions, mirroring the country's industrial, political, and artistic ambitions. Brussels' 1874 Industrial Arts Exhibition, organised entirely by private entrepreneurs, affirmed the nation's dynamism through the presentation of artefacts linked to two major domains: industrial arts and architecture $^{4}$. The exhibition aimed to promote industrial arts and their development, using decorative domestic objects. It also used the presentation of urban projects, to illustrate different aspects of the dynamism of the nation and of its capital. The exhibition encouraged the creation of a museum of industrial arts, a powerful instrument that would have implemented the development of Belgian design, thus completing the coveted reform project. The development of a museum launched by Charles Buls, a pioneer in the development and promotion of Belgian decorative arts, was well-received, but did not find an immediate realisation 5 . It was however connected to another event, the celebrations for the fiftieth anniversary of the country's independence. This gave the government the opportunity of supporting the industrial arts, using them to foment a national consciousness and encourage a feeling of national 'belonging'. While the Industrial Arts Exhibition was organised in the new iron-and-glass Halles in Brussels, a highlysymbolic building marking the progresses made by Belgian industry, the government chose an edifice specially built for the 1880 Jubilee Exhibition. This was a two-winged architecture, covered with a modern glass and iron structure centrally-interlocked with a classical triumphal arch. It reflected its ambivalent artistic intent, divided between the support for industrial arts and the need for self-representation through didactic and easily recognisable architectural models ${ }^{6}$ (Fig. 1).

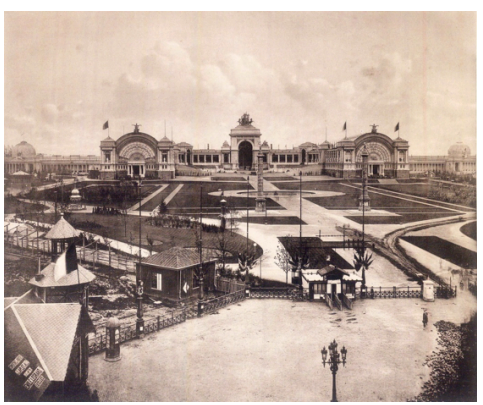

The State, therefore, sought to strengthen a progressive vision of the youthful but already powerful nation and to renew the thread of history engaging with its great artistic tradition. Available funds were mainly destined for the fête industrielle, which included two exhibitions - one focused on contemporary industrial arts, the other on

${ }^{3}$ Conseil de perfectionnement de l'enseignement des arts du dessin. Session de 1874 (1874) Bruxelles: Gobbaerts.

${ }^{4}$ Exposition des arts industriels. Bruxelles 1874. Catalogue officiel (1874) Bruxelles: Vanderauwera. ${ }^{5}$ Prina, D. N. (2012), 'Belgian decorative arts in the second half of the nineteenth century. Needs for a national museum and debates surrounding didactic collections in Brussels', Journal of the History of Collections, vol. 24(2), pp. 257-274.

${ }^{6}$ Ranieri, L. (1973), Léopold Il urbaniste, Bruxelles: Hayez, pp. 123-140. 
ancient decorative arts - both, accompanied by exhaustive catalogues? ${ }^{7}$. Industrial arts were therefore presented at the Jubilee Exhibition as the past, present and future of the nation, helping to valorise and renovate the great Belgian artistic tradition. The connection between artistic research and its practical outcomes had already been promoted by the government in Belgium's early days through the creation of institutions such as the Commission royale des monuments and the Académie royale de Belgique, which encouraged studies on national artistic heritage ${ }^{8}$. The historiographical research published for this occasion stressed the importance of the relationship between tradition and modernity, emphasising those elements that interpreted it: art, industry, architecture, and the nation. Moreover, the 1880 Jubilee Exhibition alluded to an eventual allocation of a portion of the buildings as premises for a new museum of industrial arts (opened in 1889), completing the mission of infusing "good taste" in the population. It bridged the gap between major and minor arts, directing the latter to the industrial production accomplishing the sought-for economic, political and cultural undertakings (fig. 2). In order to implement this project, and involve all social classes, the government needed to impose its central role in the design reform dynamics. It used two main initiatives. The first was the creation of a Decorative Arts School in Brussels, where new design schools created nearby in the 1860 s had already enhanced Belgian design. This was thanks to the perseverance of the new burgomaster (between 1881 and 1899) Buls. The second was the creation of a Higher Institute in Antwerp, under the full control of the government. Both projects were planned in 1879 and completed in 1886, following years of debates and negotiations.

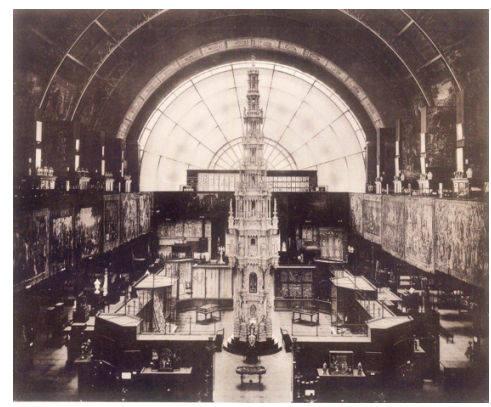

Figure 2.

Ancient Decorative Arts at the Jubilee Exhibition (1880).

\section{The ambitious project of a Higher Institute}

In this context, the creation of Antwerp's Higher Institute is particularly relevant. It highlights the government's artistic policies and its attempts to restore the centrality of Fine Arts, through which the state mostly expressed itself, by encouraging at the same time an educational system focused on decorative arts, opened-up to all social classes. The government also aimed to create both a political and cultural balance between Belgium's administrative capital, Brussels, and its artistic capital, Antwerp, seat of the country's most prestigious Academy of Fine Arts (whose teaching was completely reformed to create the Higher Institute). (Fig. 3)

${ }^{7}$ Fumière, T. (1880) Les arts décoratifs à l'exposition du Cinquantenaire belge, Brussels : Guyot ; Exposition Nationale, IV section, Industries d'Art en Belgique antérieures au XIXe siècle. Catalogue Officiel (1880) Brussels: Vanderauwera.

${ }^{8}$ Van Impe, E. (2008) 'The rise of architectural history in Belgium', Architectural History, vol. 51, pp. 161-183. 
theme 5

society

Figure 3 .

Cover of one of the Higher Institute commemorative books (1911). strand 1

design policies

Artistic education in Antwerp was indeed split in two different establishments. The Academy followed the principles of the 1874 study programme and comprised the first two degrees of theoretical, practical and decorative art education - relying on local administration and under the artistic supervision of a director. The Higher Institute, a sort of 'university of the arts' dedicated to higher artistic studies, was managed by the state only. In addition to ordinary courses, seven free workshops - including one for architecture - were opened under the direction of a renowned master, for high-level education. The two establishments thus had different directions and only shared an administrative manager, as the government still financially supported the Academy following a royal decree of 10 July 1869.

The extensive theoretical instruction offered by the reformed Academy was focused on artistic practices and its languages: it drew at various levels on art history and history of styles, touching all fields of artistic knowledge9. Using an artistic expression of strong

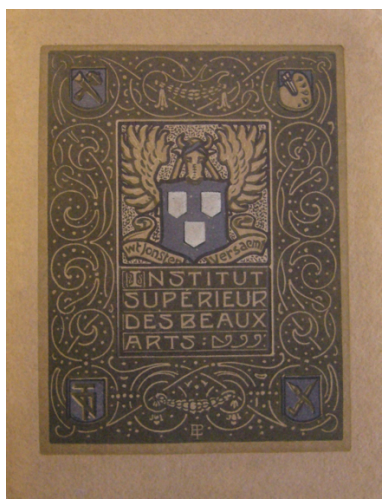

moral value and built on a renovated system of education created by the institutions, art could thus encompass all classes - strengthening the government's project of legitimising the country's unity through the creation of a national identity. Such "artistic University", offered a broader and more articulated education when compared to the previous organisation. It specifically targeted,welcomed and trained not only artists and architects but all craftsmen and workers. As a result, the national cohesion project was strengthened by giving all social classes the opportunity to be educated in the first artistic institution of the country. These artists, architects, craftsmen, would have worked in Belgian manufacturers and building yards, following practices and tastes imparted at Antwerp's Academy, whose study plan was aligned with the artistic policies supported by the government.

Moreover, the new organisation fulfilled the idea of a more rational and useful educational system. The creation of specific training for design education at lower levels was administrated locally, -thus defining the area of education for craftsmen, and connecting it, where possible, to local manufactures and building yards. The reform was also motivated by a strong desire to rebuild a national artistic identity using an unsurpassed artistic local model, the Flemish Renaissance ${ }^{10}$. The highpoint of applied arts during

\footnotetext{
9 Leerplan 1886, Archief van de Koninklijke Academie voor Schone Kunsten (hereafter AKASKA), MA 62. ${ }^{10}$ Willis A. (1984), Flemish Renaissance Revival in Belgian Architecture (1830-1930), PhD thesis, New York: Columbia University.
} 
this golden artistic age, where all the artistic forces were combined in a meaningful and valuable bundle, was thought thanks to the presence of great masters. It was therefore obvious for art institutions to take charge of their fervent mission of reunifying the arts" ${ }^{11}$.

The reorganisation also sought to position the Academy of Antwerp at a higher level than that of other national establishments, with the creation of a new atelier of Decorative and Monumental Art, and in particular, perfecting architectural education. The new atelier reflected the ambivalent ambitions of the government which wanted to improve industrial art, but primarily financed public works of art (historical paintings, commemorative monuments, erection and restoration of public buildings). This twofold attitude, oscillating between conservative drifts and the desire to renew, explains why even if the architecttraining was perfected and widened in its historical and technological aspects, in Antwerp architectural training remained largely rooted in the academic tradition.

The reform, however, did not bring the much longed-for results, for several reasons. It frustrated local ambitions: during the pre-reform debates, the municipal administration had already feared the Academy would be diminished after the reorganisation compared to other Belgian academies, as some of the 'mid-level' courses were relocated to the Higher Institute ${ }^{12}$. As a result, some courses taught at the Academy, such as 'architectural planning', received a broader extension with the aim of raising the educational level of the Academy, inevitably overlapping with teaching imparted at the Higher Institute ${ }^{13}$. This fact prevented many students from enrolling at the Higher Institute, as many of them had already received a broad education allowing them to start a career. Moreover, towards the end of the century, the administration reduced elementary courses in order to admit skilled students only ${ }^{14}$. Craftsmen and decorators, which still represented the majority of students, were thus obliged to train in industrial schools, with a subsequent collapse in the number of enrolments' ${ }^{15}$. Continuity of education, which had been at the core of the reform, was consequently broken. An analogous problem afflicted the students' passage from the Academy to the Higher Institute, for the two institutions lacked educational coordination. As a result, the Academy and the Institute were led into the new century without consistent oversight ${ }^{16}$.

\section{Conclusion}

Despite the political ambitions to establish a close relationship between art and industry - realised through continuous organisational renewal and updating educational curricula the design reforms promoted in Antwerp by the government remained disconnected from innovative contemporary artistic and architectural trends, developed mostly in Brussels' avant-garde milieux. Moreover, the highly centralised plan that identified Antwerp as the heart of the cultural life of the country failed to find appreciation in Belgium's vital and well-defined local cultural model, as it conflicted with local interests and the need

\footnotetext{
${ }^{11}$ Conseil Communal. Réorganisation de l'Académie royale des Beaux-arts d'Anvers (1880), Antwerp: De Backer, AKASKA, p. 481

${ }^{12}$ Bulletin Communal (1880) no.11, Anvers, pp. 536-586.

${ }^{13}$ Rosier J., De Taeye E.L. (1907-08), Architecture, AKASKA, MA 733.

${ }^{14}$ Rapport sur la situation et les travaux de l'Académie royale d'Anvers pendant l'année scolaire 1898-99, AKASKA, MA 235, Palmarès.

${ }^{15}$ Rosier J., De Taeye E.L. (1907-08), Annexe E "Danger de la suppression des classes élémentaires", AKASKA, dossier MA 733.

${ }^{16}$ Rosier J., De Taeye E.L. (1902-03), (1905), (1907-08), Rapports, AKASKA, MA 733
} 
to prioritise national art. The political project to unify the country through art therefore failed as well, due to the complexity of the problematic management of Belgian schools, affecting both private and public issues. Antwerp's case study thus announces the future directions followed by Belgium in the artistic and political domains. The didactic institutions of major regional towns were indeed institutionalised and strengthened, becoming active centres for the development of their own local productions:

reorganisations of academies were launched in Liège in 1905 and in Gent in 1912-13, while, after World War I, the creation in Brussels of the Higher Institute of Decorative Arts (ISAD La Cambre) in 1926 reinforced the capital's educational offer ${ }^{17}$. The gradual dissolution of the unifying project begun in the second half of the nineteenth century became effective towards the 1970s, when cultural autonomy was attributed to the Flemish and Walloon communities, thus initiating Belgium's regionalisation process later achieved in 1993.

\section{References}

Archief van de Koninklijke Academie voor Schone Kunsten, Antwerpen.

Exposition des Académies et des écoles de dessin et Congrès de l'enseignement des arts du dessin (1869) Bruxelles: Lelong.

Conseil de perfectionnement de l'enseignement des arts du dessin. Session de 1874 (1874) Bruxelles: Gobbaerts.

Exposition des arts industriels. Bruxelles 1874. Catalogue officiel (1874) Bruxelles: Vanderauwera. Fumière, T. (1880) Les arts décoratifs à l'exposition du Cinquantenaire belge, Bruxelles. Prina, D. N. (2010), 'Design in Belgium before Art Nouveau: art, industry, and the reform of artistic education in the second half of the nineteenth century', Journal of Design History, vol. 23(4), pp. 329-350. 